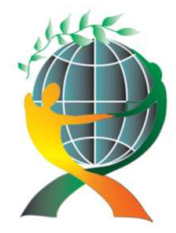

\author{
(online) = ISSN $2285-3642$ \\ ISSN-L = $2285-3642$ \\ Journal of Economic Development, Environment and People \\ Volume 7, Issue 2, 2018
}

URL: http://jedep.spiruharet.ro

e-mail: office jedep@spiruharet.ro

\title{
Quality of employment in small firms
}

\author{
A book review by Uţă Cristian ${ }^{1}$ \\ ${ }^{1}$ Spiru Haret University
}

How to cite: UȚĂ, C. (2018). Quality of employment in small firms. Journal of Economic Development, Environment and People, 7(2), 60-61. doi: http://dx.doi.org/10.26458/jedep.v7i2.586

The strategic objective of the European Union set out in Lisbon is to become the most competitive and dynamic knowledge-based economy capable of delivering sustainable economic growth, increasing employment and developing greater social cohesion. At the heart of this strategy are businesses and given that the vast majority of them are SMEs (less than 250 employees), policies to achieve this are focused on them. At the same time, improving the quality of work and working conditions is still an important objective on the European political agenda due to multiple socio-economic implications. In this context, the work "Quality of Employment in Small Companies" by Daniela Paşnicu and Gabriela Tănase is very current. Appeared in 2017 at the University Publishing House, the paper is structured in five chapters.

For the first time, the authors present the "Conceptual and Dimensional Framework for Measuring the Quality of Employment". The necessary semantic clarifications are followed by an analysis of the evolution of the concept of employment quality from the point of view of statistical measurement. In a synthesis of research on the multidimensionality of the concept are presented the seven essential dimensions of the concept:

1. Safety and ethics of work;

2. Revenue and benefits from employment;

3. Working time and work-life balance - personal life;

4. Occupational safety and social protection;

5. Social dialogue;

6. Skills development and training;

7. Professional relations and motivation of work.

The second chapter, "Technical Aspects and Main Outcomes at European and International Level in Measuring Employment and Labour Quality" focuses on choosing indicators to measure this quality. The typology of these indicators is analysed, be it static or dynamic indicators, objective or subjective indicators. It is also debated the issue of choosing a synthetic indicator to respond to the multidimensional quality of 


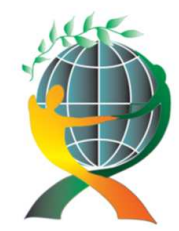

\author{
(online) $=$ ISSN $2285-3642$ \\ ISSN-L = $2285-3642$ \\ Journal of Economic Development, Environment and People \\ Volume 7, Issue 2, 2018 \\ URL: http://jedep.spiruharet.ro \\ e-mail: office jedep@spiruharet.ro
}

occupation. Other technical issues addressed refer to the information sources that can provide the data necessary for the calculation of these indicators. The authors present the main European surveys.

In the third chapter entitled "Analysis of Romanian business strategies, policies, measures and perceptions

In the third chapter entitled "Analysis of strategies, policies, measures and perceptions of the Romanian business environment regarding the development of SMEs", two SWOT analyzes are elaborated:

- SWOT analysis of Romania's strategies, policies, measures for development, through the impact of the effects on the quality of employment, and the

- SWOT analysis of business perceptions as a basis for developing future directions for action.

In the fourth chapter there is a "Comparative analysis, in dynamics of small enterprises on employment from a quantitative and qualitative perspective". A first part of the chapter focuses on analyzing the dynamics of small businesses and their staff by activity, in relation to enterprises in other size classes. It is highlighted that most SMEs operate in the trade sector, while most medium and large enterprises are active in the industry. In the second part, the quality of employment in SMEs is analyzed in terms of employment quality indicators on continuous training. One of the conclusions drawn is that managers invest little in human resource training (an average of $1.96 \%$ of turnover), as staff training is a necessity in the knowledge economy.

The last chapter proposes "Directions for action to increase the quality of employment" that specifically target the specific needs of small firms. These directions are presented in a synthetic way, and they can contribute substantially to providing decent work for as many people as possible. Perhaps the main observation is that "innovation must not only belong to an elite of small businesses but to all those who have potential that can lead to productivity improvements, job growth and decent living."

\title{
References
}

[1] D. Paşnicu, G. Tanase, Quality of employment in small firms University Publishing House, Bucharest, 2017 